\title{
Microbial Biomass in the Soils of Burned and Unburned Japanese Red Pine Forests in the Setouchi District, Western Japan
}

\author{
TAKahiro TATEISHI* and TAKao Horikoshi** \\ Department of Environmental Studies, Faculty of Integrated Arts and Sciences, \\ Hiroshima University, Higashi-Hiroshima 724, Japan \\ (Received August 15, 1994 - Accepted January 4, 1995)
}

\begin{abstract}
Microbial biomass in the soils of burned and unburned Japanese red pine forests in the Setouchi District, Western Japan was determined by a slightly modified chloroform fumigation-incubation method. Averages \pm standard deviations of microbial biomass carbon (C) of 36 unit samples in the 0$5 \mathrm{~cm}$ soil layers at burned sites located in Ato and Nenoura were $307 \pm 206$ and $789 \pm 274 \mathrm{mg} \mathrm{kg}^{-1} \mathrm{dry}$ soil, respectively, and that at an unburned site at Ato was $408 \pm 213 \mathrm{mg} \mathrm{kg}^{-1}$ dry soil. Soil microbial biomass $\mathrm{C}$ at the burned sites were approximately the same or slightly higher than at the unburned site. In contrast with soil microbial biomass, the above-ground plant biomass at the burned sites was about one-fifth or one-sixth of that at the unburned site. Microbial biomass $\mathrm{C}$ in the FH layer at the unburned site at Ato was $13.38 \pm 6.13 \mathrm{~g} \mathrm{~kg}^{-1}$ dry soil. No significant fluctuations of microbial biomass were observed through 1 year in the $0-5 \mathrm{~cm}$ soil layers at either the burned and unburned sites, nor in the FH layer at the unburned site. The ratios of microbial biomass $\mathrm{C}$ to total $\mathrm{C}$ in the soils at the burned sites were $3.2-3.3 \%$, significantly higher than those at the unburned site $(2.1 \%)$. Significant correlations were observed between microbial biomass $\mathrm{C}$ and some soil characteristics, such as contents of total $\mathrm{C}$, total nitrogen $(\mathrm{N})$ and water, in both burned and unburned soils.
\end{abstract}

Key words : Soil microbial biomass, Pinus densiflora forests, forest fires, chloroform fumigationincubation method

\section{Introduction}

Many large forest fires have occurred, mainly in early spring, in the Pinus densiflora Sieb. et Zucc. (Japanese red pine) forests along the coast of the Seto Inland Sea, Western Japan. In the burned sites, $P$. densiflora forests naturally regenerated 20-30 years after the fire ${ }^{25)}$.

It is well known that microbial biomass in soil plays an important role as a pool of mineral nutrients for plant growth ${ }^{2,23)}$. So to understand the roles of microorganisms in the secondary suc-

* Present address : Laboratory of Forest Ecology, Department of Forestry, Faculty of Agriculture, Kyoto University, Kyoto 606, Japan.

** Corresponding author. cession after the fires, it is necessary first to determine the soil microbial biomass.

Several studies have been made of the effects of fire on flora and the numbers of microorganisms in the soils, in forests of black wattle ${ }^{24)}$, Douglas fir ${ }^{43)}$, jack pine ${ }^{1)}$, loblolly pine ${ }^{20)}$, lodgepole pine ${ }^{41)}$, spruce $\mathrm{fir}^{7)}$ and Australian eucalyptus ${ }^{38)}$, as well as in the prairie ${ }^{40)}$ and the Adenostoma chaparral ${ }^{8)}$, but there have been only a few investigations into the effects of fire on microbial biomass in spruce fir forest $^{7)}$, chaparral ${ }^{12)}$ and tropical forest ${ }^{21}$.

Previously, we applied the chloroform fumigation-incubation method to the estimation of soil microbial biomass in the burned and unburned Japanese red pine forests ${ }^{36)}$, and showed that microbial biomass $\mathrm{C}(\mathrm{M})$ could be determined 
using the formula, $\mathrm{M}=\left\{\right.$ (the amount of $\mathrm{CO}_{2}-\mathrm{C}$ evolved from the fumigated soil for $0-10$ days after fumigation, $\mathrm{F}$ ) - (the amount of $\mathrm{CO}_{2}-\mathrm{C}$ evolved from the fumigated soil for 10-20 days after fumigation, $\left.\left.F^{\prime}\right)\right\} / k_{c}$, instead of Jenkinson's convensional formula, $\mathrm{M}=\left\{\mathrm{F}-\right.$ (the amount of $\mathrm{CO}_{2}-\mathrm{C}$ evolved from the unfumigated soil for 10-20 days after fumigation, $\left.\left.U F^{\prime}\right)\right\} / \mathbf{k}_{\mathrm{c}}{ }^{18)}$. The $\mathbf{k}_{\mathrm{c}}$ value was determined as 0.3 , using 3 fungal and 3 bacterial cultured species as internal standards ${ }^{36)}$.

The purposes of this study were to estimate the size of microbial biomass in the soils at burned and unburned sites, using our slightly modified fumigation-incubation method ${ }^{36)}$, and to determine the environmental factors which affect the size of microbial biomass in the study sites.

\section{Materials and Methods}

\section{Study sites}

The investigation sites in the present study were two burned Japanese red pine forests at Ato and Nenoura and a single unburned red pine forest at Ato in Yasuura-cho in the south of Hiroshima Prefecture, western Japan. This region has a warm-temperate monsoon climate. The average annual mean temperature and annual precipitation during the 10-year period from 1980 to 1989 in Kure Meteorological Station, 15-20 km west of the investigation sites were $15.5^{\circ} \mathrm{C}$ and $1,442 \mathrm{~mm}$, respectively. Monthly mean air temperatures reach their maximum in August and minimum in January or February. Precipitation is lower in winter and higher throughout the summer except in August.

The plant community in the forest vegetation along the coast of Seto Inland Sea in Hiroshima Prefecture belongs to the Rhododendro-reticulatiPinetum densiflorae $H$. Suzuki et Toyohara $1971^{25)}$ and the pine forests before fires had the same association. The investigation sites are located on the slopes of mountains with elevations of $100-140 \mathrm{~m}$; the slope aspects are southeastsouth-southwest and slope angles $10-30^{\circ}$.
The age of the unburned forest was about 30 years. Fire occurred on April 6-7, 1983 at the Nenoura site (burned area, $94 \mathrm{ha}$ ), and on May 910, 1984 at Ato (burned area, $81 \mathrm{ha}$ ). All $P$. densiflora trees in the burned sites were killed by fire. All or part of the $A_{0}$ horizon was burned away. The succession of vegetation which regenerated after the fires near the study sites has been investigated by Nakagoshi et al. ${ }^{25)}$ At the burned sites, dominant shrubs, Eurya japonica Thunb., Quercus serrata Murr., Rhododendron kaempferi Planch. and Rhododendron reticulatum D. Don, had regenerated from sprouts from the remaining stumps, while dominant herbs, Miscanthus sinensis Andress. and Dicranopteris dichotoma Bernh., had regenerated from shoots from the remaining subterranean organs. The recovery speed of vegetation is generally slow; a third of the surface of the ground was bare even 4 years after the fire at Nenoura, as was half the surface of the ground 3 years after the fire at Ato. In the unburned site at Ato, the dominant tree species is $P$. densiflora Sieb. et Zucc. The number of individuals was $23 / 100 \mathrm{~m}^{2}$ and their mean diameter at breath height was $12.1 \mathrm{~cm}$, but $96 \%$ of the pine trees in the area had been blighted with a pine sawyer. The dominant shrubs are E. japonic $a$ and $R$. reticulatum. The ground surface of the unburned site was covered with $D$. dichotoma.

To determine the above-ground plant biomass the terrestrial parts of all shrubs and herbs were cut down at the base in one or two quadrats $\left(2 \times 2 \mathrm{~m}^{2}\right)$ at the burned sites in September 1987. Plant materials were dried at $80^{\circ} \mathrm{C}$ for 3 days, and then weighed. The above-ground tree biomass was calculated using the diameter at breath height and tree height using the empirical formulae of Nishioka et al. ${ }^{30}$ ) The above-ground plant biomass at the burned sites at Ato (3.5 years after the fire) and Nenoura ( 4.5 years after the fire), and at the unburned site at Ato were 284, 381 and 1,720 $\mathrm{g} \mathrm{m}^{-2}$ respectively.

The $A_{0}$ horizon was absent or very thin $(<1 \mathrm{~cm})$ at the burned sites and about $5 \mathrm{~cm}$ thick at the 
unburned site at Ato. The A horizon was just below $1 \mathrm{~cm}$ at all sites.

\section{Characteristics of soils}

Characteristics of the soil at each study site are shown in Table 1. The details of soil analyses have been described in our previous paper ${ }^{36)}$. The total carbon content was determined by the dry combustion method with a C-N corder (MT-500, Yanagimoto Co. Ltd., Japan).

Almost all the total $\mathrm{C}$ in the soils of the present study is considered to be organic because: (1) The content of soil organic $\mathrm{C}$ is usually underestimated by the Tyurin method, as compared with the dry combustion method ${ }^{15}$. Although such tendency was observed in a preliminary experiment of the present study, the values of organic $\mathrm{C}$ content in the present soils determined by the Tyurin method reached about $90 \%$ of those determined with a C-N corder. (2) The $\mathrm{pH}$ of the mineral soil at the present investigation sites was acidic. Furthermore, the soil samples did not effervesce when $4 \mathrm{~N} \mathrm{HCl}$ solution was added dropwise to the wetted soil sample ${ }^{29}$, indicating that the soil did not contain the carbonate $\mathrm{C}$.

Soils were classified according to the system proposed by the Forest Soils Divison of the Government Forest Experiment Station ${ }^{13)}$.

\section{Sampling of soils}

For sampling of soils, a $20 \mathrm{~m} \times 20 \mathrm{~m}$ square subdivided with 4-m grids was set up at each study site. Essentially, the surface $5 \mathrm{~cm}$ samples of the mineral soil layer, each of which consisted of a single core, were taken with a $100 \mathrm{ml}$ core sampler (diameter, $5.1 \mathrm{~cm}$ ) at the 36 grid intersections. The unburned site samples were also taken from the FH horizon, the mean thickness of which was $3.7 \mathrm{~cm}$.

In the case of investigations of seasonal changes in microbial biomass, a $1 \mathrm{~m} \times 1 \mathrm{~m}$ square subdivided with $0.2-\mathrm{m}$ grids was set up at the place representing the ecosystem of each site, and 4 top soil $(0-5 \mathrm{~cm})$ samples, each consisting of a single core, were taken from the resulting 25 subsquares $(0.2$ $\mathrm{m} \times 0.2 \mathrm{~m}$ ) using a randomized method to minimize the variabilities arising from topographic heterogeneity.

Soil samples were stored overnight at $15^{\circ} \mathrm{C}$ before use.

Table 1. Characteristics of soils at the study sites.

\begin{tabular}{|c|c|c|c|}
\hline & \multicolumn{2}{|c|}{ Burned sites } & \multirow{2}{*}{$\frac{\text { Unburned site }}{\text { Ato }}$} \\
\hline & Ato & Nenoura & \\
\hline Parent material & $\begin{array}{l}\text { Weathered } \\
\text { granite }\end{array}$ & $\begin{array}{l}\text { Weathered } \\
\text { rhyorite }\end{array}$ & $\begin{array}{l}\text { Weathered } \\
\text { granite }\end{array}$ \\
\hline Texture & SL & $\mathrm{L}$ & $\mathbf{L}$ \\
\hline Classification & Immature & $\begin{array}{l}\text { Yellowish } \\
\text { Brown Forest }\end{array}$ & Immature \\
\hline $\begin{array}{l}\text { Bulk density of } \\
\text { upper } 5 \mathrm{~cm} \\
\left(\mathrm{~g} \mathrm{~cm}^{-3}\right)\end{array}$ & 1.02 & 0.91 & 0.92 \\
\hline \multicolumn{4}{|l|}{$\mathrm{pH}$ of upper $5 \mathrm{~cm}$} \\
\hline$\left(\mathrm{H}_{2} \mathrm{O}\right)$ & 4.8 & 4.7 & 4.3 \\
\hline$(\mathrm{KCl})$ & 3.9 & 3.7 & 3.4 \\
\hline Total C & 1.0 & 2.5 & 2.0 \\
\hline $\begin{array}{l}\text { Total N } \\
\text { of upper } 5 \mathrm{~cm} \mathrm{( \% )}\end{array}$ & 0.04 & 0.09 & 0.10 \\
\hline
\end{tabular}




\section{Measurement of soil microbial biomass by chloroform fumigation-incubation method}

Soil samples were passed through an 8-mm sieve immediately before use. Microbial biomass in the soils was determined by a slight modification of Jenkinson and Powlson's method ${ }^{18)}$. Thirty grams of the moist soil in a $100-\mathrm{ml}$ beaker was fumigated for $24 \mathrm{~h}$. Then $120 \mathrm{mg}$ of fresh soil were inoculated, and the soil's moisture content was ajusted to $55 \%$ of its water holding capacity. Incubation of the fumigated soil was done using $1.5 l$ polyethylene tanks (High-pack, Sunplatec Co. Ltd., Osaka, Japan). After the cap provided with the tank was lined with adhesive vinyl tape. The amount of $\mathrm{CO}_{2}$ trapped in the alkaline solution was determined with the method described by Jenkinson and Powlson ${ }^{18)}$. Soil microbial biomass $\mathrm{C}(\mathrm{M})$ was calculated by the following formula ${ }^{36)}, \mathrm{M}=\left\{\left(\right.\right.$ amount of $\mathrm{CO}_{2}-\mathrm{C}$ evolved from the fumigated soil $0-10$ days after fumigation, $\mathrm{F}$ ) - (amount of $\mathrm{CO}_{2}-\mathrm{C}$ evolved from the fumigated soil 10-20 days after fumigation, $\left.\left.\mathrm{F}^{\prime}\right)\right\} / \mathrm{k}_{\mathrm{c}}$ where $\mathrm{k}_{\mathrm{c}}$ was the fraction of the biomass $\mathrm{C}$ mineralized to $\mathrm{CO}_{2}-\mathrm{C}$ during the first 10 days of incubation after fumigation-inoculation. $A \mathrm{k}_{\mathrm{c}}$ value of 0.30 was used in the present study ${ }^{36}$.

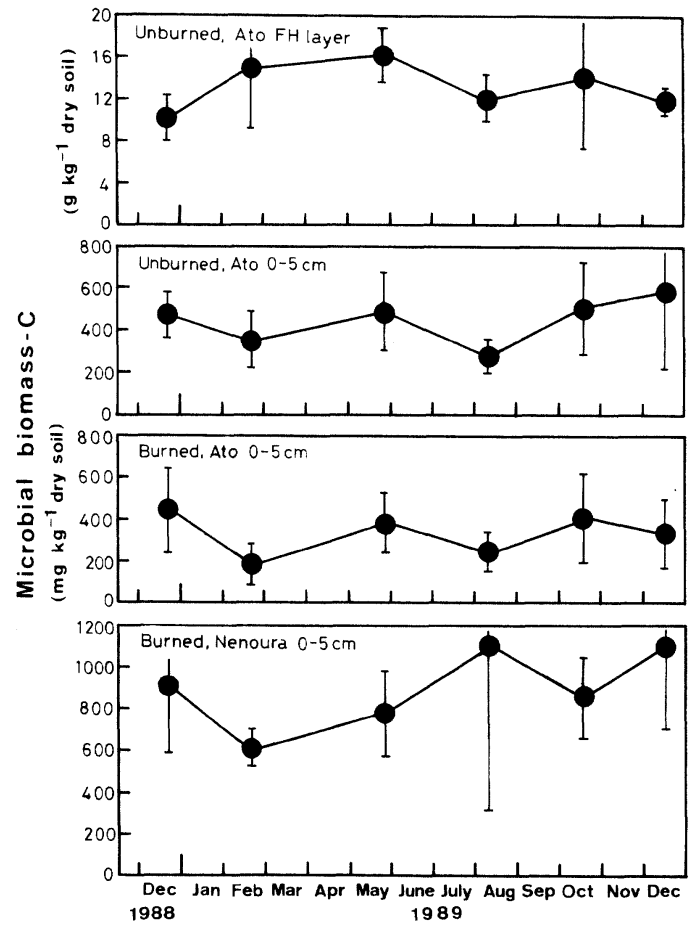

Fig. 1. Seasonal fluctuations in microbial biomass $\mathrm{C}$ in the $0-5 \mathrm{~cm}$ mineral soil layer of the burned sites at Ato and Nenoura and the unburned site at Ato, and in the FH layer of the unburned site at Ato. Vertical bars indicate standard deviation.

Table 2. Microbial biomass $\mathrm{C}$, total $\mathrm{C}$, total $\mathrm{N}$ and the ratios of biomass $\mathrm{C}$ to total $\mathrm{C}$ in the soils of the burned sites at Ato and Nenoura and the unburned site at Ato.

\begin{tabular}{|c|c|c|c|c|c|c|c|c|c|}
\hline \multirow{2}{*}{\multicolumn{2}{|c|}{$\begin{array}{l}\text { Sites and } \\
\text { soil layers }\end{array}$}} & \multirow{2}{*}{$\begin{array}{l}\text { Sampling } \\
\text { date }\end{array}$} & \multirow{2}{*}{$\begin{array}{l}\text { Months } \\
\text { after } \\
\text { burning }\end{array}$} & \multicolumn{2}{|c|}{ Microbial biomass $\mathrm{C}^{a}$} & \multicolumn{2}{|c|}{ Total $\mathrm{C}^{a}$} & \multirow{2}{*}{$\begin{array}{l}\text { Total Na } \\
\left(\mathrm{g} \mathrm{m}^{-2}\right)\end{array}$} & \multirow{2}{*}{$\begin{array}{l}\text { Ratio of } \\
\text { biomass C to } \\
\text { total } C^{a}(\%)\end{array}$} \\
\hline & & & & (mg kg-1 dry soil) & $\left(\mathrm{g} \mathrm{m}^{-2}\right)$ & $(\%)$ & $\left(\mathrm{kg} \mathrm{m}^{-2}\right)$ & & \\
\hline \multicolumn{10}{|c|}{ Burned sites } \\
\hline Ato & $0-5 \mathrm{~cm}$ & Nov. 1988 & 54 & $\begin{array}{c}307 \pm 206 \\
(0.67)^{b}\end{array}$ & $14.8 \pm 8.9$ & $0.99 \pm 0.52$ & $0.48 \pm 0.18$ & $20.1 \pm 7.3$ & $3.2 \pm 1.6$ \\
\hline Nenc & $0-5 \mathrm{~cm}$ & Apr. -May 1989 & $72-73$ & $\begin{array}{c}789 \pm 274 \\
(0.35)^{b}\end{array}$ & $34.2 \pm 10.1$ & $2.45 \pm 0.74$ & $1.06 \pm 0.24$ & $40.5 \pm 9.9$ & $3.3 \pm 0.7$ \\
\hline \multicolumn{10}{|c|}{ Unburned site } \\
\hline \multirow[t]{2}{*}{ Ato } & FH layer & June 1989 & - & $\begin{array}{c}13380 \pm 6130 \\
(0.46)^{b}\end{array}$ & 53.5 & N.D. ${ }^{c}$ & N.D. ${ }^{c}$ & N.D. ${ }^{c}$ & N.D. ${ }^{c}$ \\
\hline & $0-5 \mathrm{~cm}$ & June 1989 & - & $\begin{array}{c}408 \pm 213 \\
(0.52)^{b}\end{array}$ & $18.1 \pm 8.3$ & $1.98 \pm 0.79$ & $0.88 \pm 0.29$ & $42.0 \pm 16.3$ & $2.1 \pm 0.8$ \\
\hline
\end{tabular}

\footnotetext{
${ }^{a}$ Average of 36 replicate samples \pm standard deviation.

$b$ The value shown in parentheses indicates the coefficient of variation.

${ }^{c}$ N.D., not determined.
} 


\section{Results}

Microbial biomass $C$ in the soils at the burned and unburned sites

Microbial biomass $\mathrm{C}$ in the soil was determined at the burned site at Ato in November 1988, at the other site, at Nenoura, in April-May 1989, and at the unburned site at Ato in June 1989. As is shown in Table 2, microbial biomass $\mathrm{C}$ in the mineral soil layer at the burned and unburned sites ranged from 307 to $789 \mathrm{mg} \mathrm{kg}^{-1}$ dry soil, and that in the FH horizon at the unburned site was far greater than those in the mineral soil layer at the burned and unburned sites. The coefficients of variation were very large at all the investigation sites. There was no significant difference in terms of biomass $\mathrm{C}$ in the mineral soil layer between the burned and unburned sites at Ato. However, biomass $\mathrm{C}$ in the mineral soil layer at the burned site at Nenoura was significantly higher than at the burned and unburned sites at Ato $(\mathrm{P}<0.05)$.
Microbial biomass $\mathrm{C}$ on an area basis are also shown in Table 2. Microbial biomass $\mathrm{C}$ per $\mathrm{m}^{2}$ in the upper $5 \mathrm{~cm}$ mineral soil is nearly the same for the burned and unburned sites at Ato, and is larger at Nenoura. Microbial biomass $\mathrm{C}$ on an area basis is highest in the $\mathrm{FH}$ horizon at the unburned site at Ato.

The proportions of microbial biomass $\mathrm{C}$ to total $\mathrm{C}\left(\mathrm{C}_{\mathrm{mic}} / \mathrm{C}_{\mathrm{tot}}\right)$ in the mineral soil layers were 3.2 $3.3 \%$ at the two burned sites and $2.1 \%$ at the unburned site at Ato. The $\mathrm{C}_{\text {mic }} / \mathrm{C}_{\text {tot }}$ value at the unburned site was significantly lower than at the burned sites at the $\mathrm{P}<0.05$ level.

Seasonal changes in microbiol biomass $C$ in the soils at the burned and unburned sites

Seasonal changes in soil microbial biomass $\mathrm{C}$ were investigated at the burned sites at Ato and Nenoura and at the unburned site at Ato during the period from December 1988 to December 1989 (Fig. 1). Microbial biomass $\mathrm{C}$ in the $0-5 \mathrm{~cm}$ soil

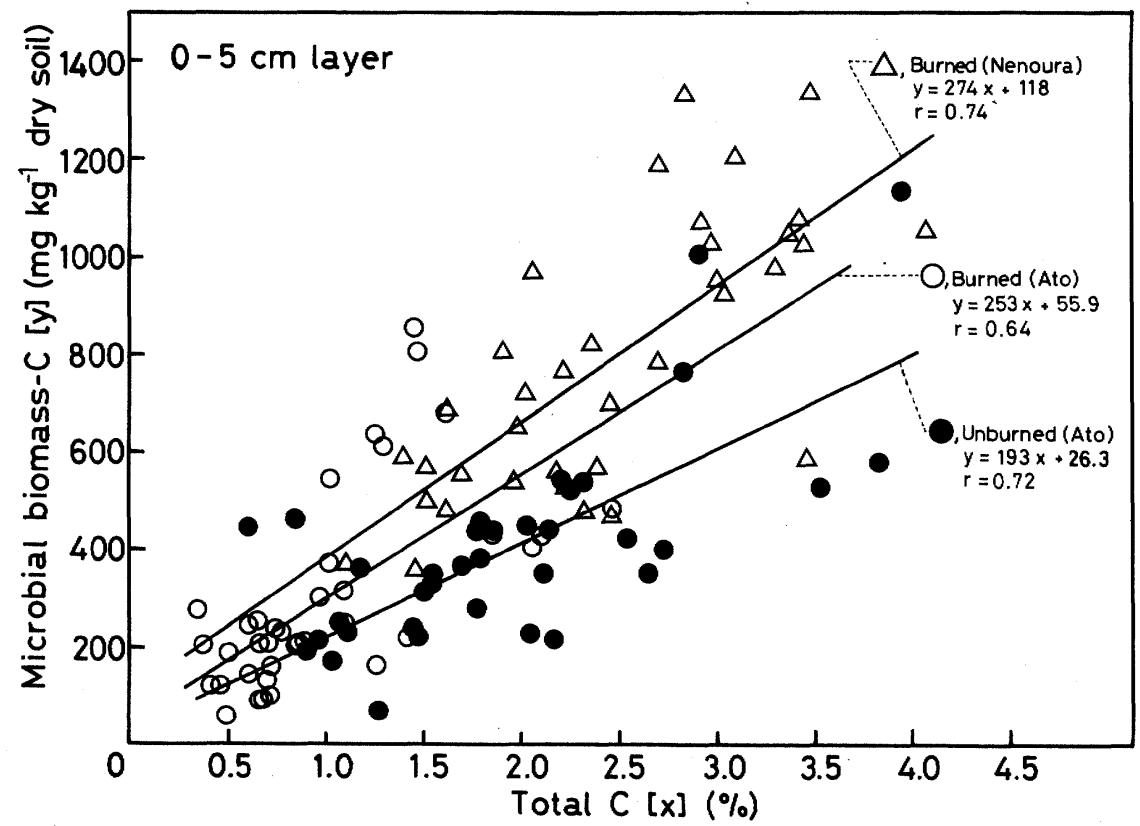

Fig. 2. Correlations between contents of total $\mathrm{C}$ and microbial biomass $\mathrm{C}$ in the mineral soils of the burned sites at Ato and Nenoura and the unburned site at Ato. O, burned site at Ato; $\triangle$, burned site at Nenoura; $\bullet$, unburned site at Ato. 
layer at the burned site at Ato ranged from 186 to $443 \mathrm{mg} \mathrm{kg}{ }^{-1}$ dry soil, that at the burned site at Nenoura from 604 to 1094, and that at the unburned site at Ato from 280 to 592. Duncan's new multiple range test revealed no significant differences in microbial biomass $C$ in the $0-5 \mathrm{~cm}$ soil layer of the various sites during the investigation period at the $\mathbf{P}>0.05$ level. Microbial biomass $\mathrm{C}$ in the $\mathrm{FH}$ horizon at the unburned site at Ato fluctuated between $10.3-16.2 \mathrm{~g} \mathrm{~kg}^{-1}$ dry soil, and showed no significant changes $(\mathrm{P}>0.05)$.

Relationships between microbial biomass $C$ and the contents of total $C$, total $N$ or water in the soils

To investigate the environmental factors which affect the size of microbial biomass, the relationships between microbial biomass $\mathrm{C}$ and some soil properties were analyzed by regression analyses using 36 replicate samples for each study site. The soils used were identical to those described in
Table 2.

Figure 2 shows the correlations between contents of total $\mathrm{C},(\mathrm{x}, \%)$ and biomass $\mathrm{C}\left(\mathrm{y}, \mathrm{mg} \mathrm{kg}^{-1}\right.$ dry soil) in the soils. Significant correlations were observed between the contents of total $\mathrm{C}$ and biomass for the three soil groups at the $\mathrm{P}<0.001$ level, indicating that microbial biomass in the soil is dependent upon total $\mathrm{C}$ content. The slope angle of the regression line at the burned site at Nenoura was significantly steeper than at the unburned site at Ato at the $\mathrm{P}<0.2$ level, though there was no significant difference between the burned and unburned sites of Ato at the same probability level.

The correlations between the contents of total $\mathrm{N}$ $(\mathrm{x}, \%)$ and biomass $\mathrm{C}(\mathrm{y})$ in the soils are shown in Fig. 3. Significant correlations were observed between the contents of total $\mathrm{N}$ and biomass $\mathrm{C}$ for all soils at the $\mathrm{P}<0.001$ level. The slope angles of the regression lines at the burned sites were significantly steeper than at the unburned site $(\mathrm{P}<0.05)$.

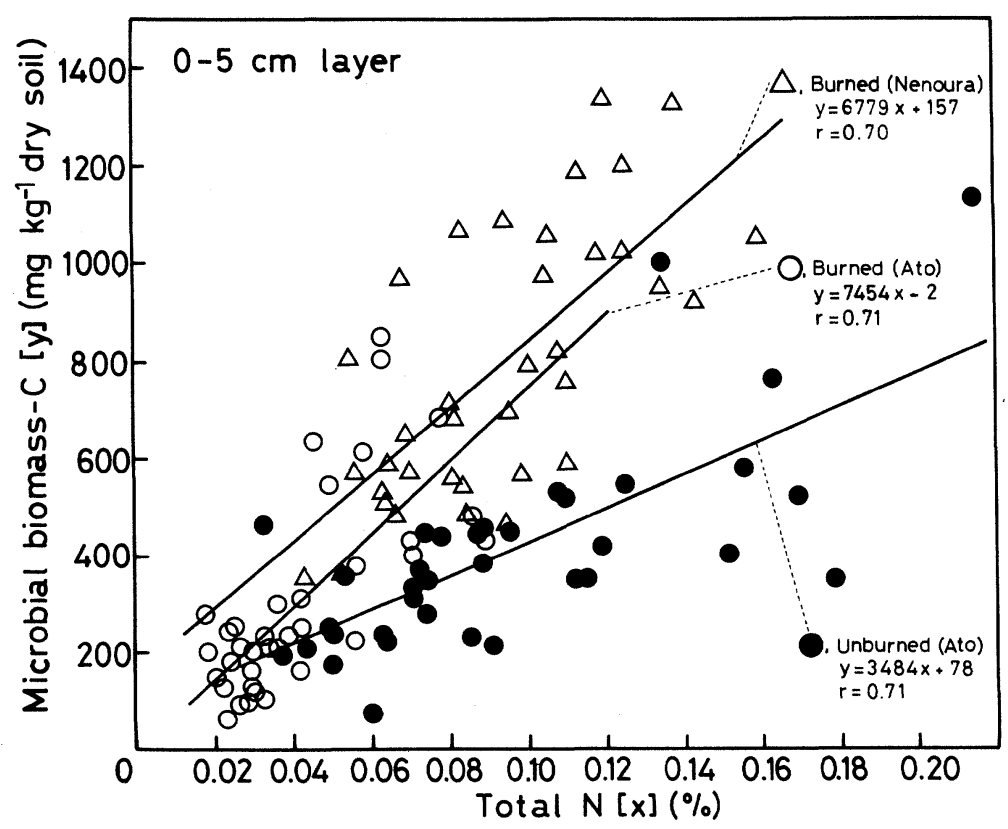

Fig. 3. Correlations between contents of total $\mathrm{N}$ and microbial biomas $\mathrm{C}$ in the mineral soils of the burned sites at Ato and Nenoura and the unburned site at Ato. 0 , burned site at Ato; $\Delta$, burned site at Nenoura; $\bullet$, unburned site at Ato. 


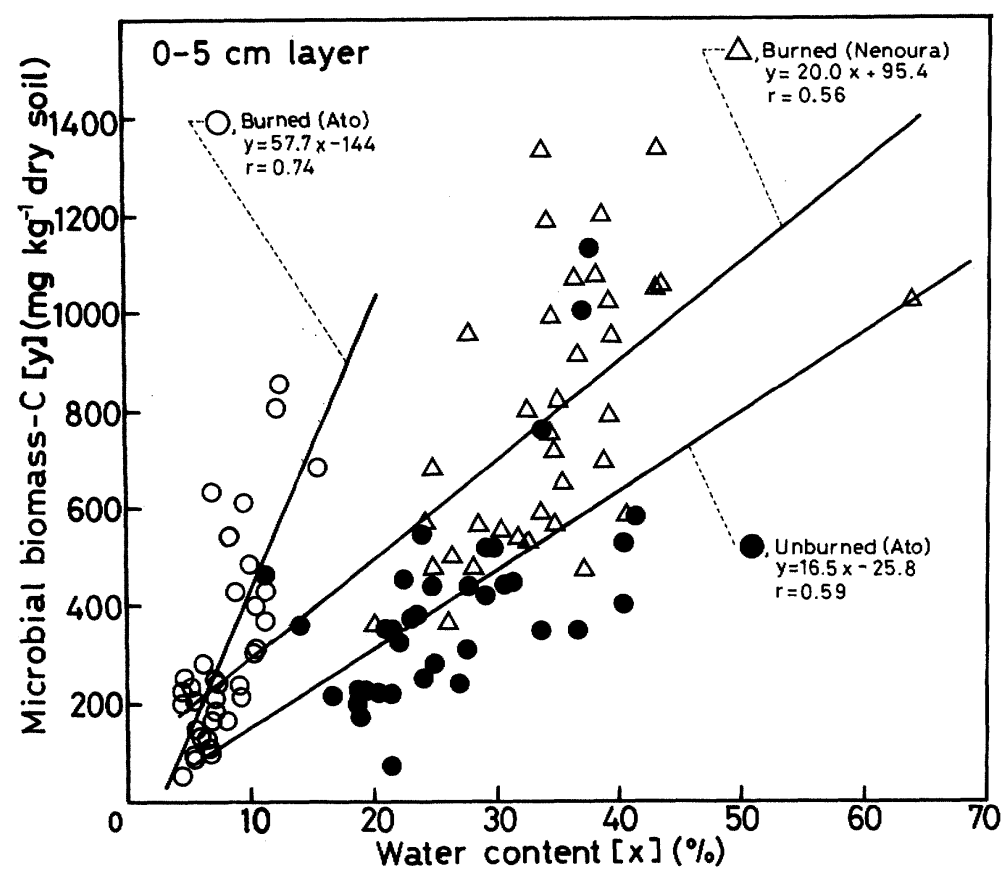

Fig. 4. Correlations between water content and microbial biomass $\mathrm{C}$ in the mineral soils of the burned sites at Ato and Nenoura and the unburned site at Ato. O, burned site at Ato; $\triangle$, burned site at Nenoura; $\bullet$, unburned site at Ato.

Figure 4 shows the correlations between the contents of water $\left(x_{2} \%\right)$ and biomass $C(y)$ in the soils. The correlations between the contents of water and biomass $\mathrm{C}$ were significant for all soils $(\mathrm{P}<0.001)$, indicating that microbial biomass in the soils are dependent upon soil water contents, at least in the range between a few percent and $60 \%$. The slope of the regression line at the burned site at Ato was significantly steeper than those at either the burned site at Nenoura or the unburned site at Ato $(\mathrm{P}<0.05)$.

\section{Discussion}

Thirty-six soil samples were systematically taken from the $20 \mathrm{~m} \times 20 \mathrm{~m}$ quadrat at each site. The coefficients of variation (C.V.) of microbial biomass obtained with this sampling method in the mineral soil layer were in the range from 52 to $67 \%$ at Ato and $35 \%$ at Nenoura, and $46 \%$ in the FH horizon at Ato (Table 2). Speir et al ${ }^{34)}$ took 10 topsoil $(0-5 \mathrm{~cm})$ samples with approximately even spacing at the small uniform site $(8.2 \mathrm{~m} \times 5.4 \mathrm{~m})$ under grazed pasture and found $18 \% \mathrm{C} . \mathrm{V}$. for soil respiratory activity. Accordingly, our C.V. values about soil biochemical properties were far larger than those of Speir et al. ${ }^{34)}$ We consider the causes of this phenomenon to be as follows: The present investigation sites were situated on the mountain slopes, where the ground surface was uneven, and the states of the soil horizon in the sites differed from one part of the ground to another. As a result, the physicochemical (the deposition of organic matter on the ground surface and the contents of organic matter and water in the soil, etc.) and the biological (vegetation etc.) properties differed from one part of the ground to another. Moreover, some parts of the ground surface at the burned sites were bare, and others had vegetation. Probably the topographic and 
vegetational heterogeneities are the causes of the wide variability in the physicochemical and biological characteristics of the soils. The lesser variability at Nenoura, as compared with that at Ato, may be due to the differences in the sites' positions on the mountain slopes; the study site at Nenoura was situated on the upper part of the mountain slope, and hence its ground surface was more even.

Microbial biomass $\mathrm{C}\left(\mathrm{mg} \mathrm{kg}^{-1}\right.$ dry soil) determined in the mineral soils of various unburned forests have been reported as follows: 480 in the $0-15 \mathrm{~cm}$ soil layer of the tropical forest of Nigeria $^{4)} ; 1,060$ of the $0-23 \mathrm{~cm}$ of the deciduous forest of England ${ }^{18)} ; 430-1,900,720$ and $720-1,410$ in the $0-10 \mathrm{~cm}$ soil layers of the oak, hawthorn and ash forests, respectively, of England ${ }^{39)}$; 588-723 and 361 in the $5-15 \mathrm{~cm}$ soil layers of the pine and oak forests of Spain ${ }^{10)}$; and 466-744 in the 0-10 $\mathrm{cm}$ soil layers of the dry tropical forests of India $^{31,33)}$. On the other hand, microbial biomass $\mathrm{C}$ in soils of burned forests were as follows : 400 $\mathrm{mg} \mathrm{kg}{ }^{-1}$ dry soil in the $0-5 \mathrm{~cm}$ soil layers of the burned chaparral in California ${ }^{12)} ; 829 \mathrm{mg} \mathrm{kg}^{-1}$ dry soil in the $0-5 \mathrm{~cm}$ soil layers of the slashedand-burned forest in Brazil ${ }^{21)}$. These biomass values in the mineral soil layers are almost the same order as those obtained in the present studies. However, microbial biomass $\mathrm{C}$ in the $\mathrm{FH}$ horizon in this study (13.38 $\mathrm{g} \mathrm{kg}^{-1}$ dry soil) was 3-21 times larger than that observed in the Pinus sylvestris forests of U.K. (0.64-3.2 $\mathrm{g} \mathrm{kg}^{-1}$ dry soil) ${ }^{42)}$ or the Pinus contorta forests of Montana (2.97-5.34 g $\mathrm{kg}^{-1}$ dry soil) $)^{11)}$. This may be due to the following two reasons. (1) In the former sites, the $\mathrm{pH}$ $\left(0.01 \mathrm{M} \mathrm{CaCl}_{2}\right)$ of $\mathrm{FH}$ horizon (2.7) was far lower than that $(1 \mathrm{M} \mathrm{KCl})$ of the present study (3.6). Such a strongly acidic condition might repress the microbial activity. (2) In the latter sites, the organic soils contained much pine needle litter which was less decomposable than the FH samples.

Microbial biomass in the soils at the burned sites were not so different from that seen at the unburn- ed site, and were even higher at Nenoura. This result was somewhat unexpected since even a few years after the fire the above-ground plant biomass at the burned sites was about one-fifth or one-sixth that at the unburned site, as described in Materials and Methods, and the greater part of the ground surface was bare at the burned sites, indicating a smaller input of organic matter to the soil from vegetation. In our previous paper ${ }^{37)}$, we reported a similar phenomenon at 4 burned (2-80 months after burning) and one unburned Japanese red pine forests near the present investigation sites, using composite topsoil $(0-2 \mathrm{~cm})$ samples. Bissett and Parkinson $^{7)}$ reported that microbial biomass in the soils of a burned spruce fir forest 5 years after a fire stood at a level similar to that of the unburned forest. Fenn et al. ${ }^{12)}$ also reported that microbial biomass in the soils of a burned chaparral was similar to those of the unburned soils. The phenomenon in the study sites might be attributed to the following two causes: (1) The amounts of litter fall and the respiration rates of the $A_{0}$ horizon of a red pine forest were nearly identical to those of an evergreen oak forest, however the amount of organic $\mathrm{C}$ on the floor of a red pine forest was about three times that of an evergreen oak forest. The amount of organic $\mathrm{C}$ transported from the $\mathrm{A}_{0}$ horizon to the mineral soil layer and that deposited in the mineral soil layer of a red pine forest was half of those of an evergreen oak forest $^{26,27)}$. These results show that the mineral soil layer of a Japanese red pine forest had less substrates which could be utilized by soil microorganisms than did the same layer of an evergreen oak forest situated at the same altitude in Japan. The microorganisms in a red pine forest seem to be limited by the availability of carbon and the level of microbial biomass may not be greatly affected by the cessation of or decrease in the supply of organic matter by vegetation. (2) Nakane et $a l .{ }^{28)}$ showed that almost all the organic $\mathrm{C}$ in mineral soil was retained for a few years after the clear cutting of trees and raking of the $A_{0}$ layer in a Japanese red pine forest in Fuchu-cho, Hiro- 
shima Prefecture. This shows that organic matter in mineral soil are stable over a fairly long period, even after the destruction of vegetation. We demonstrated that microbial biomass in the soil correlated significantly with the amount of organic matter in the soil, as shown in Fig. 2. If the level of organic matter in the mineral soil is constant for a fairly long period following the destruction of vegetation, the soil microbial biomass might also maintain a constant level after a fire. The above two causes might well contributed to the maintenance of a constant level of microbial biomass in soil for a fairly long period even after a fire.

The seasonal fluctuations of microbial biomass were observed in the mineral soils of the Picea maliana forest in Alaska ${ }^{9)}$ and dry tropical forest in India ${ }^{31,33)}$, and in the FH horizon of a lodgepole pine forest in Montana ${ }^{11}$. However, in the present study we could not find significant differences in microbial biomass $\mathrm{C}$ during the different seasons at the $\mathrm{P}=0.05$ probability level. One reason for this difference might be the great spatial variability, which apparently masked differences in microbial biomass and in biological characteristics in the present soil ecosystem, although four soil replicates were taken from a small site $(1 \mathrm{~m} \times 1 \mathrm{~m})$. Speir et al ${ }^{34)}$ also described a similar phenomenon in which the values of biological properties varied greatly between adjacent cores, $1 \mathrm{~cm}$ apart, in the grassland. The second reason is as follows : as described above there were few substrates for microbial growth and its maintenance in soils of a Japanese red pine forest, so the soil remains in an oligotrophic state. The microorganisms in such a soil environment seem to be well adapted to this state and have many features characteristic of microbial "K" strategists ${ }^{22)}$, i.e., a low respiration rate, a slow rate of cell division and a long turnover time ${ }^{19}$. Perhaps the soil microorganisms in the red pine forest also have the same features, enabling those to maintain a constant level of biomass irrespective of seasonal fluctuations in environmental conditions.

The ratios of microbial biomass $\mathrm{C}$ to total $\mathrm{C}$ content in the soils $\left(\mathrm{C}_{\mathrm{mlc}} / \mathrm{C}_{\mathrm{tot}}\right)$ at the burned sites at Ato and Nenoura and the unburned site at Ato were $3.2,3.3$ and $2.1 \%$ respectively, with the ratios at the burned sites being significantly higher than that at the unburned site. Total $\mathrm{C}$ in the present soils substantially implies the organic $\mathrm{C}$ as described in the Materials and Methods. Anderson and Domsch ${ }^{3)}$ determined the ratios of microbial biomass $\mathrm{C}$ to organic $\mathrm{C}$ contents $\left(\mathrm{C}_{\mathrm{mic}} / \mathrm{C}_{\text {org }}\right)$ of 134 arable soils and showed that the ratios were 2.3 for permanent monocultures and 2.9 for continuous crop rotation. The ratios arose just after the plots had been treated with organic fertilizers as green manure ${ }^{3)}$. According to Insam and Domsch ${ }^{17)}$, the ratios of $\mathrm{C}_{\mathrm{mic}} / \mathrm{C}_{\text {org }}$ immediately after afforestation in open-pit reclamation sites were $15-20 \%$ and these decreased with time, reaching constant values of $2 \% 45$ years after afforestation. Beck ${ }^{5)}$ proposed that the overall index of soil microbial activity (Bodenmikrobiologische Kennzahl, BMK) which was calculated from the measurements of some enzyme activities and microbial biomass $\mathrm{C}$ in soils, reported that the ratio of $\mathrm{BMK} / \mathrm{C}_{\text {org }}$ could be used as indicator of whether soil organic matter was in equilibrium, or whether it was accumulating or decreasing; he asserted that higher $\mathrm{BMK} / \mathrm{C}_{\text {org }}$ values were an indication of ongoing accumulation. These results suggest that, at the burned sites in the present study, with their higher $\mathrm{C}_{\mathrm{mic}} / \mathrm{C}_{\text {tot }}$ ratios, organic matter was accumulating in the soil. On the other hand, at the unburned site, with its lower $\mathrm{C}_{\mathrm{mic}} / \mathrm{C}_{\text {tot }}$ ratio, organic matter in the soil was either in a state of equilibrium or decreasing.

In the present study, the microbial biomass $\mathrm{C}$ correlated significantly with the amount of total $\mathrm{C}$ in the soil. The slopes of regression lines between microbial $\mathrm{C}$ and total $\mathrm{C}$ in the burned soils were steeper than that of the unburned soil. This tendency was similar to the ratios of $C_{\text {mic }} / C_{\text {tot }}$ for the burned and unburned sites. This shows that the microbial biomass maintained by the unit amount of total $\mathrm{C}$ is different for the burned and unburned sites. One or more of the following factors may 
have led to this result: First, regenerated vegetation in the burned sites was composed of broadleave shrubs and herbs, whereas vegetation on the unburned site was dominated by pine trees. So needles and twigs of pine trees were densely accumulated on the floor of the pine forest. Thus, the quality of organic matter in the burned soil might well have been quite different from that in the unburned soil. Generally, the decomposition rate of broadleave litter is higher than that of needle litter ${ }^{35}$ ) and the amount of water-soluble organic carbon in the organic layer of hardwood forests was larger than that of coniferous forests ${ }^{16)}$. Sakamoto and $\mathrm{Oba}^{32)}$ reported that microbial biomass $\mathrm{C}$ was highly correlated with the amount of water-soluble organic carbon. These points would suggest that the proportion of readily decomposable organic $\mathrm{C}$ in the soils at the burned sites might be higher than at the unburned sites. As a result, the biomass per unit amount of organic $\mathrm{C}$ in the burned soils might become higher than in the unburned soil. Second, Berg et al. ${ }^{6)}$ have found that the needle litter of Scots pine contained substances which inhibited fungal growth. It is highly possible that the growth of microorganisms in the soils at the unburned site might have been restricted by some substances contained in needle litter, and that this inhibitive effect resulted in a decrease in the proportion of microbial biomass $\mathrm{C}$ to total $\mathrm{C}$ content. Third, the composition of the microbial community in the burned soil was different from that of the unburned soil ${ }^{7,41)}$. If the same phenomenon was observed in the present investigation sites, and the utilization efficiency of substrates by microbial communities was different for the burned and unburned soils, then the biomass per unit amount of organic $\mathrm{C}$ might also tend to be different.

The slopes of the regression lines showing the relationship between microbial biomass $\mathrm{C}$ and total $\mathrm{N}$ content in the burned soils were also steeper than in the unburned soil. The contents of inorganic and readily decomposable nitrogens in burned soil were far larger than in unburned soil $^{12,14)}$. Furthermore, in unburned soil, a greater part of the inorganic $\mathrm{N}$ may be absorbed by plants. The higher proportions of inorganic and readily decomposable $\mathrm{N}$ in burned soils may be related to the steeper slopes of the regression lines.

Significant correlations were also seen between microbial biomass $\mathrm{C}$ and water content. The slopes of the regression lines were different from site to site. If microbial biomass $\mathrm{C}$ are plotted against the percentages of water content to the maximum water-holding capacity on the basis of $100 \mathrm{~g}$ dry soil (WC/WHC), significant correlations are not observed between them. This is because the WC/WHC values tend to converge to the specific value for each site. Perhaps the differences in the slopes may be due to the differences in the mean WC/WHC values at the sampling time; the mean WC/WHC values at the burned sites at Ato and Nenoura and the unburned site at Ato were 19,47 , and $45 \%$, respectively. The mean WC/WHC values might be influenced by the precipitation and the soil aridity before sampling : The precipitation in November is generally lower than those in April, May or June in the present study area as described in our previous paper ${ }^{37}$.

Organic $\mathrm{C}$ serves as an energy source and is an important factor in the production of new microbial cells. Nitrogen is also one of the primary elements constituting microbial cells. Moisture conditions are closely related to activities of microorganisms in nature. Therefore, soil microbial biomass might well respond sensitively to changes in the contents of total $\mathrm{C}$, total $\mathrm{N}$ and water in the soils of the burned and unburned sites in the present study.

\section{Acknowledgements}

The authors wish to express sincere thanks to the members of the Yasuura-cho city hall and the owners of the forests investigated for making the study area available. The authors are particularly indebted to Dr. Fumiki Takahashi, Emeritus Professor of Hiroshima University, Dr. Nobukazu 
Nakagoshi, Associate Professor of Hiroshima University, and the late Dr. Susumu Kuraishi, Professor Emeritus of Hiroshima University, for their many suggestions throughout the present study. The authors are also indebted to $\mathrm{Mr}$. Tsukasa Nakagawa and Miss Naoko Inoue for their invaluable assistance.

\section{References}

1) Ahlgren, I.F. and C.E. Ahlgren. 1965. Effects of prescribed burning on soil microorganisms in a Minnesota jack pine forest. Ecology 46 : 304310.

2) Anderson, J.P.E. and K.H. Domsch. 1980. Quantities of plant nutrients in the microbial biomass of selected soils. Soil Sci. 130: 211216.

3) Anderson, T.H. and K.H. Domsch. 1989. Ratios of microbial biomass carbon to total organic carbon in arable soils. Soil Biol. Biochem. 21 : 471-479.

4) Ayanaba, A., S.B. Tuckwell and D.S. Jenkinson. 1976. The effects of clearing and cropping on the organic reserves and biomass of tropical forest soils. Soil Biol. Biochem. 8 : 519-525.

5) Beck, Th. 1984. Mikrobiologische und biochemische Charakterisierung landwirtschaftlich genutzter Boden. II. Mitteilung. Beziehungen zum Humusgehalt. Z. Pflanzenernaehr. Bodenkd. 147: 467-475.

6) Berg, B., K. Hannus, T. Popoff and O. Theander. 1980. Chemical components of Scots pine needles and needle litter and inhibition of fungal species by extractives. Ecol. Bull. 32 : 391-400.

7) Bissett, J. and D. Parkinson. 1980. Long-term effects of fire on the composition and activity of the soil microflora of a subalpine, coniferous forest. Can. J. Bot. 58 : 1704-1721.

8) Christensen, N.L. and C.H. Muller. 1975. Effects of fire on factors controlling plant growth in Adenostoma chaparral. Ecol. Monogr. 45 : 29-55.

9) Cochran, V.L., L.F. Elliott and C.E. Lewis. 1989. Soil microbial biomass and enzyme activity in subarctic agricultural and forest soils. Biol. Fertil. Soils. 7 : 283-288.

10) Diaz-Ravina, M., T. Carballas and M.J. Acea. 1988. Microbial biomass and metabolic activity in four acid soils. Soil Biol. Biochem. 20 : 817823.

11) Entry, J.A., N.M. Stark and H. Loewenstein. 1986. Effect of timber harvesting on microbial biomass fluxes in a northern Rocky Mountain forest soil. Can. J. For. Res. 16: 1076-1081.

12) Fenn, M.E., M.A. Poth, P.H. Dunn and S.C. Barro. 1993. Microbial N and biomass, respiration and $\mathrm{N}$ mineralization in soils beneath two chaparral species along a fire-induced age gradient. Soil Biol. Biochem. 25 : 457-466.

13) Forest Soils Division. 1976. Classification of forest soils in Japan. Bull. Gov. For. Exp. Stn. Jpn. 280 : 1-28 (in Japanese with English summary).

14) Fujita, H. 1988. Fluctuation of soil chemical properties immediately after fire on the secondary oak forest in northeastern part of Japan. Ecol. Rev. (Sendai) 21 : 221-225.

15) Higashi, T., in "Standardized Analytical Methods of Soil”, ed. by Y. Onikura et al. Hakuyuhsha, Tokyo, 1986, pp. 77-94 (in Japanese).

16) Hu, L., C.T. Youngberg and C.M. Gilmour. 1972. Readily oxidizable carbon: an index of decomposition and humification of forest litter. Soil Sci. Soc. Am. Proc. 36 : 959-961.

17) Insam, H. and K.H. Domsch. 1988. Relationship between soil organic carbon and microbial biomass on chronosequences of reclamation sites. Microb. Ecol. 15 : 177-188.

18) Jenkinson, D.S. and D.S. Powlson. 1976. The effects of biocidal treatments on metabolism in soil. V. A method for measuring soil biomass. Soil Biol. Biochem. 8 : 209-213.

19) Joergensen, R.G., P.C. Brookes and D.S. Jenkinson. 1990. Survival of the soil microbial biomass at elevated temperatures. Soil Biol. Biochem. 22 : 1129-1136.

20) Jorgensen, J.R. and C.S. Hodges, Jr. 1970. Microbial characteristics of a forest soil after twenty years of prescribed burning. Mycologia 62: $721-726$

21) Luizao, R.C.C., T.A. Bonde and T. Rosswall. 1992. Seasonal variation of soil microbial biomass-the effects of clearfelling a tropical rainforest and establishment of pasture in the central Amazon. Soil Biol. Biochem. 24: 805813.

22) Lynch, J.M. 1984. Interactions between biological processes, cultivation and soil structure. Plant Soil 76: 307-318.

23) Marumoto, T., J.P.E. Anderson and K.H. Domsch. 1982. Mineralization of nutrients from soil microbial biomass. Soil Biol. Biochem. 14: 469-475.

24) Meiklejohn, J. 1955. The effect of bush burning on the microflora of a Kenya upland soil. J. Soil Sci. 6 : 111-118.

25) Nakagoshi, N., K. Nehira and F. Takahashi, in 
"The Role of Fire in Ecological System", ed. by L. Trabaud. SPB Academic Publishing, Hague, 1987, pp. 91-119.

26) Nakane, K. 1975. Dynamics of soil organic matter in different parts on a slope under evergreen oak forest. Jpn. J. Ecol. 25 : 206-216 (in Japanese with English summary).

27) Nakane, K., H. Tsubota and M. Yamamoto. 1984. Cycling of soil carbon in a Japanese red pine forest. I. Before a clear-felling. Bot. Mag. 97 : 39-60.

28) Nakane, K., H. Tsubota and M. Yamamoto. 1987. Simulation of soil carbon cycling following clear cutting in a Japanese red pine forest. J. Jpn. For. Soc. 69 : 417-426.

29) Nelson, D.W. and L.E. Sommers, in "Methods of Soil Analysis, Part 2, Chemical and Microbiological Properties, 2nd eds.”, ed. by A.L. Page, R.H. Miller and D.R. Keeney. Amer. Soc. Agro., Inc. and Soil Sci. Soc. Amer., Inc., Madison, 1982, pp. 539-579.

30) Nishioka, M., T. Umehara and M. Nagano, in "Ann. Rep. Census. Jap. Monkey Mt. Mino 1981”, ed. by Edu. Commit. of Mino City, Osaka. 1982, pp. 117-139 (in Japanese).

31) Raghubanshi, A.S. 1991. Dynamics of soil biomass $\mathrm{C}, \mathrm{N}$, and $\mathrm{P}$ in a dry tropical forest in India. Biol. Fertil. Soils. 12 : 55-59.

32) Sakamoto, K. and Y.Oba. 1991. Relationship between various soil organic substances by the Waksman's analysis and soil biomass. Jpn. J. Soil Sci. Plant Nutr. 62 : 107-114 (in Japanese with English summary).

33) Singh, J.S., A.S. Raghubanshi, R.S. Singh and S.C. Srivastava. 1989. Microbial biomass acts as a source of plant nutrients in dry tropical forest and savanna. Nature 338 : 499-500.

34) Speir, T.W., D.J. Ross and V.A. Orchard. 1984. Spatial variability of biochemical properties in a taxonomically-uniform soil under grazed pasture. Soil Biol. Biochem. 16: 153-160.

35) Takeda, H., Y. Ishida and T. Tsutsumi. 1987. Decomposition of leaf litter in relation to litter quality and site conditions. Mem. Coll. Agric. Kyoto Univ. 130 : 17-38.

36) Tateishi, T., T. Horikoshi, H. Tsubota and F. Takahashi. 1989. Application of the chloroform fumigation-incubation method to the estimation of soil microbial biomass in burned and unburned Japanese red pine forests. FEMS Microbiol. Ecol. 62 : 163-172.

37) Tateishi, T., T. Horikoshi, F. Takahashi and H. Tsubota. 1989. Microbial biomass and microflora in the soils at burned and unburned Japanese red pine forests. Bulletin of Japanese Society of Microbial Ecology 4 : 77-87.

38) Theodorou, C. and G.D. Bowen. 1982. Effects of a bushfire on the microbiology of a south Australian low open (dry sclerophyll) forest soil. Australian Forest Research 12: 317-327.

39) Vance, E.D., P.C. Brookes and D.S. Jenkinson. 1987. Microbial biomass measurements in forest soils : The use of the chloroform fumigationincubation method in strongly acid soils. Soil Biol. Biochem. 19 : 697-702.

40) Wicklow, D.T. 1973. Microfungal populations in surface soils of manipulated prairie stands. Ecology 54 : 1302-1310.

41) Widden, P. and D. Parkinson. 1975. The effects of a forest fire on soil microfungi. Soil Biol. Biochem. 7 : 125-138.

42) Williams, B.L. and G.P. Sparling. 1984. Extractable $\mathrm{N}$ and $\mathrm{P}$ in relation to microbial biomass in UK acid organic soils. Plant Soil 76: $139-148$.

43) Wright, E. and W.B. Bollen. 1961. Microflora of Douglas-fir forest soil. Ecology 42 : 825-828. 